\title{
REVISION OF THE NEGOTIABLE INSTRUMENTS LAW
}

\author{
ROSCOE B. TURNER
}

In the latter part of 1926, the National Conference of Commissioners on Uniform State Laws, through its Committee on Amendments of Uniform Acts, undertools the preparation of a series of amendments to the Negotiable Instruments Law. The time for such action seemed particularly appropriate inasmuch as the act had then been adopted by all of the states, though with minor variations in text in many cases. There had been $a$ considerable amount of experience with the statute; for in the principal commercial states it had been in effect from twenty to thirty years. That there was need for some action to harmonize the conflicting interpretations which had developed, and possibly to reconcile the variations in provisions of the different statutes, was scarcely open to question, if the original objective, a uniform body of law relating to negotiable paper, was to be realized to the extent reasonably possible. The committee designated Professor Williston to undertake the work, a singularly happy appointment.

At the outset a question arose in the committee as to whether a comprehensive revision of the act should be undertaken, the alternative being to draft only such amendments as would be necessary to correct the more serious conflicts. Practically, there is much force in the argument for the latter alternative, as it is a long and difficult process to get uniform legislative action in each of the forty-eight states. This argument works both ways, however, as it has been suggested that any action at this time, if it must be adopted in all states before any other steps are taken, would postpone for many years the drafting of any additional amendments that might later seem desirable. Thus the attempt at the beginning to agree upon a formula of comprehensive or limited revision was probably waste motion. Of first importance would be a survey of all points regarded as perhaps needing amendment.

There is, however, room for considerable discussion as to the character of any revision, whether limited or comprehensive in scope. Should it be confined, in the interest of greater clarity and accuracy of expression, to the correction of verbal inconsistencies in the present act? There are many of these, as would no doubt be true in the case of any piece of legislation covering so involved a subject. But notwithstanding these difficulties, 
it is believed that the statute has in the main proven itself to be a highly satisfactory piece of legislation. ${ }^{1}$ Hence it is at least doubtful whether a series of amendments designed to make incidental improvements in wording, where in thirty years of operation there has been little or no difficulty in the courts on the points in question, would receive or indeed merit much legislative attention. Of course, insofar as amendments strike at actual misinterpretations prevailing in a particular state, it would be a considerable gain to have them adopted in the interest of uniformity. The net result of such changes, however, would be merely to write into the law, somewhat more positively and definitely, the rules approved when the act was first drafted, or to set up the common law decisions as the principle guide to revision.

It would be of much greater moment, and would result in greater benefit, if the committee should undertake, perhaps at this time with regard to only a limited number of points, a very thoroughgoing and comprehensive investigation of the facts involved. This of course would be quite a different thing from a mere attempt to square the statute with decisions antedating its adoption. It might well take several years. While common law decisions would be entitled to much weight in such an inquiry, there is no reason to believe that they should bo taken as the last word on the subject: that results arrived at by courts in other times and with other conditions before them are necessarily the perfect answer for today. Certainly no one has yet made anything comparable to such an investigation.

Of the many illustrations that could be used to make the point clearer only two or three can be considered. To any one familinr with banking practice, it is common knowledge that there has been a considerable increase in the use of acceleration provisions in time notes since the Negotiable Instruments Law was drafted. The Act expressly recognized the clause in use in installment notes at the time it was drafted which provided for the accelerntion of maturity on non-payment of principle or interest. The Act was drawn to provide that such clauses should not affect negotiability. ${ }^{2}$ But in recent years lenders have sought to employ many other types of clauses: for example, provisions for acceleration on failure to deposit additional collateral, on failure - to pay taxes or insurance premiums, or in event of failure in business. The statute provides simply that an instrument to be negotiable must be payable on demand, or at a fixed or determinable future time, and that if payable on a contingency it can

1 The editor of BRANNAN, NEgotiable INSTRUMENTS LAW (4th ed. 1026) states in the preface that the Act has "made great advances upon the common law."

2 Negotiable INStruments LAw § 2 (3). 
not be negotiable. ${ }^{3}$ It is, of course, common case-book learning that the decisions on the negotiability of instruments containing such provisions are, as might be expected, in conflict."

What should be done by way of amendment? 'Ihis calls for a determination of what should be the principal considerations guiding the committee to its decisions. And this inquiry calls in question most of the principles of negotiable instruments law. Would a more extensive use of such clauses hinder the free circulation of commercial paper? Would it introduce elements of uncertainty which should not be allowed in commercial paper? Would it operate to give lenders an unfair advantage over borrowers?

If it be assumed that some extension of the use of such clauses might well be approved without affecting negotiability, what, if any, restrictions should be imposed? Do the same considerations apply to notes, drafts, and corporate or government bonds? Should an attempt be made to distinguish between types of clauses, approving only those having to do with the loan or its security ? $^{5}$ Should the automatic or self-executing provision be declared to be operative only at the option of the holder; rather than immediately on the happening of the event of default? ${ }^{\circ}$ And should the subsequent bona fide purchaser of an instrument which has been accelerated automatically, or declared due by a prior holder, take the instrument as over-due paper subject to defenses? ${ }^{\text {? }}$

Before an answer may be given to these questions, there are certain somewhat general considerations which should be taken into account. Obviously in this situation what courts have said in the past, while a factor, is yet not one of chief importance. In the writer's view, the first consideration in amending the statute on this point, as indeed in arriving at a judicial decision in the absence of statute, should be to formulate a result which agrees, insofar as possible, with the understanding and convenience of all parties. The rule adopted by either court or legislature is not essentially different from what it would be if spelled out as one term in the contractual relationship of the parties. In the interest of convenience then, if court or legislature is to draft the contract, it should be one that accords with the

3 Ibid. § 4.

4 For example, see Holliday State Bank v. Hofiman, S5 Kan. 71, 116 Pac. 239 (1911), 35 L. R. A. (N. S.) 390 (1912).

5 See Chafee, Acceleration Provisions in Time Paper (1919) 32 Harv. L. REv. 747.

6 The federal rule is understood to be that acceleration does not occur in any case until the holder elects to declare it due. See Chicago Ry. v. Merchants' Nat'l Bank, 136 U. S. 26S, 10 Sup. Ct. 999 (1S90).

7 Hodge v. Wallace, 129 Wis. 84, 108 N. W. 212 (1906) (holder held to have acquired over-due paper subject to defenses). 
basis on which most future transactions would normally be had. The rule must be understood in order to avoid as far as possible so-called mistakes of law.

Of perhaps equal importance is the consideration that court or legislature must guard against overreaching, or unfair practice. The rule adopted must square with the ethics of the community. And as a third consideration it is obviously desirable, where possible, that the rule adopted should be one that can easily be applied by the courts. In many situations, of course, as in the adoption of the "reasonable time" test for due presentment to charge indorsers, it has been thought impossible to formulate such a rule and the question has been frankly left for the courts to decide as cases arise. ${ }^{8}$ Some of these situations probably cannot be avoided, but their number should be strictly limited. If the rule accords with general convenience and understanding, that fact alone in most cases gives assurance that it is reasonably fair, and will not require continual recourse to the courts for further construction.

The above is no doubt known by all; the difficulty is to draft provisions in accord with it. If these are important considerations, it would seem to follow necessarily that the decision whch will survive as the good legislative rule must be formulated with thorough knowledge of the facts. This is not to disregard the possibility that in many situations business may accommodate itself to any one of several rules so long as the rule ultimately adopted is definite and understandable. In such case, the decision may turn on the personal force of the advocate of one view as opposed to another. Nor do the above views overlook the fact that many decisions have been good where the court or legislature appears to have relied largely on its own good sense. In some cases the only practicable method is that of trial and error. But eyen in the usual case it is only rarely that available data has been given the weight to which it is entitled.

In the case of the present illustration, the experience of Wisconsin should be of considerable value. That state, in adopting the act, modified it by providing that an instrument payable at a fixed or determinable future time might be payable before

\footnotetext{
8 Negotiable InSTRUMents LAW $\$ 71$, discussed infra p. 45.

${ }^{9}$ In the opinion of Justice Holmes the endeavor should be made oven in tort law. See HoLmes, THE Common LAW (1881) 111, where it is said, ". . . the featureless generality, that the defendant was bound to use such care as a prudent man would do under the circumstances ought to be continually giving place to the specific one, that he was bound to use this or that precaution under these or those circumstances." It is of course much more important in commercial transactions that a definite rule should be formulated so that a person may know in advance just what is or is not sanctioned.
} 
then on the happening of a contingency. ${ }^{10}$ To the witer this would seem to square with the above general considerations. It is readily understood by users of commercial paper. It should be convenient, much more so than drawing a separate acceleration agreement. It would seem to call for no fine spun judicial interpretations. This much would seem to be a good guess, but why guess? What has been the experience? 'Has it been fair to borrowers? Has there been any diminution in the interest rate to compensate for the increased security to lenders? Has the clause proven too broad, indicating that an attempt should be made to define the types of contingencies that may be allowed? In other words whatever reliance court, or legislature, may have in its own good judgment, it is doubly secure if buttressed with the facts that an investigation such as is here suggested should disclose. Any other course is hopelessly unscientific.

There is another illustration which might well be used. At present there is in course of litigation in New York a question as to whether the refusal by a bank to certify a check should constitute a dishonor, so as to permit of immediate recourse against the drawer. ${ }^{11}$ Banks have asserted that certification was merely an accommodation on their part which they could grant or withhold at pleasure; and this view was reflected in an early New York case.12 On the other hand, the Negotiable Instruments Law is more plausibly construed as taking the view that refusal to certify counts at least as a dishonor; whether or not the bank should be responsible to its customer for injury to credit. There has, however, been a large increase in the use of checks and of certification in recent years. Is it today desirable to rule that the holder must go through the additional formality of demanding payment in order to be entitled to recourse against secondary parties? Do banks have any tangible reasons for their position? Does their view contribute to the most efficient use of checks or the reverse? Do users of checks generally understand that a refusal to certify is not a dishonor as refusal to pay would be? Answers to these questions can best be ascertained by a fact inquiry. They should be answered before an opinion is given.

There are many other illustrations, some of them involving still other considerations. To take one of the most familiar, it has been held in Illinois that where a bank certifies a raised

\footnotetext{
${ }^{10}$ See Thorpe v. Mindeman, 123 Wis. 149, 101 N. W. 417 (1904) (the provision was used to good effect to sustain the negotiability of a mortgage note containing a provision for acceleration in case of failure on the part of the mortgagor to pay taxes or to keep the property insured).

I1 Wachtel v. Rosen, 228 N. Y. Supp. 476 (App. Div. 1st Dept. 1923); (1928) 38 YALE L. J. 112.

12 Bradford v. Fox, 39 Barb. 203 (N. Y. 1863).
} 
check it obligates itself to pay the holder, at least if bona fide, the amount of the item as it existed when certified. ${ }^{13}$ The statute is at least as reasonably interpreted to obligate the bank only to the extent of the original tenor of the instrument. The decision must turn largely on the general considerations involved. It may be hazarded that there is no general understanding on the point, or, if there is, that the view of banks is contrary to that of holders. There is no unfair dealing involved on the part of the parties to the controversy, nor would one result more than the other clash with the ethics of the community. Furthermore it is doubtful whether any convincing evidence can be obtained to show that either result would tend to increase or diminish the use of certified checks appreciably, although, so far as the writer is aware, no attempt has been made to investigate this, or any of the facts in the case.

The point of greatest prominence in the case is that a loss has occurred through nothing that may be ascribed to the fault of either holder or bank. Although possible, it is no doubt impractical for the parties to stipulate who should bear this risk; thus the convenience feature as above discussed is not a guide. It would seem the important consideration here would be to determine first which party could best avoid the loss in the majority of cases-whether the merchant taking the check from the forger, or the bank in making certification. Next in importance would be to determine whether the bank or the occasional holder could best distribute the loss. ${ }^{14}$ This again calls for a careful investigation of the facts. The result, whatever view is taken, no doubt could be stated definitely enough to obviate further judicial interpretation.

The foregoing deals with only three problems that might well be considered in revising the statute, although, it may be said in passing, they have apparently as yet received little attention from the committee. There may well be disagreement as to whether the major considerations pointed out as underlying the decision in these few illustrations are really controlling.

${ }_{13}$ National City Bank v. Nat'l Bank of the Republic, 300 Ill. 103, 132 N. E. 832 (1921). The case has been generally disapproved. Seo BRANNAN, op. cit. supra note 1 , at 571 .

14 It is the writer's understanding that it was the assumed answers to these questions which as much as any other consideration moved Professor Llewellyn and Professor Breckinridge to approve of the Illinois case, supra note 13. See Comment (1922) 31 Yale L. J. 522. The chiof reasons stated, that the result favored the increased use of certified checks, and that such increase is desirable, may well be assumed.

As further illustration Lord Mansfield's decision in Price v. Neal, 3 Burr. 1354 (1762), putting upon the drawee the responsibility for possible forgery of the drawer's signature, would seem definitely, in point of fact, to meet the tests here suggested. 
Certainly they are not the only considerations to be given weight. There may also be disagreement as to the utility of fact investigation, and the tacit switch from the common law decisions to the results of such investigations as the principal basis for revision. These however will serve to throw some light on the value of the work of the committee. And in the ensuing discussion of the amendments suggested by Professor Williston there will be further opportunity to check the value of the tests here set forth.

The first series of amendments drafted by Professor Williston was submitted to the committee at its meeting in August, 1927, and generally approved. In July, 1928, a second draft modifying the first only slightly was presented to the committee at its Seattle meeting. Here, too, there appears to have been only approval of the amendments suggested, but the matter was tabled for one more year at which time it is expected final action will be taken. The list of amendments is then to be placed before the different state legislatures for adoption.

Before taking up the committee's amendments in detail, a word is necessary as to the history of some of the principal ones. When the act was first drafted, and after it had been adopted in some four states, Dean Ames of the Harvard Law School made a scathing criticism of the whole project, specifying a great many points which he regarded as requiring amendment."3 Several years later, after the act had been adopted in a large number of states substantially as drafted, the more important of Dean Ames' suggestions, together with some others, were urged by Professor Brannan also of the Harvard Law School as necessary amendments to the statute. ${ }^{10}$ These were subsequently approved by Professor Chafee in the latest edition of Brannan, and Professor Williston has added his sanction by including many of them in the present draft of amendments. During the year Professor Williston's ver'sion has been approved as to policy and with few exceptions as to wording by Professor Kent and Professor Britton in very able articles. ${ }^{17}$ In fact, it may be said the chief criticism to date has been not of the content of the amendments, but of the failure of the committee to take up many other points thought to be equally, if not more, in need of attention. ${ }^{13}$ In

15 The various articles growing out of this criticism are cited in the preface to BraNNAN, op. cit. supra note 1 , at iv.

${ }^{16}$ Brannan, Some Necessary Amendinents of the Negotiable Instruments Law (1913) 26 HARV. L. REv. 493.

17 Britton, Proposed Amendments to the Uniform Negotiable Instruments Law (1928) 22 IuL. L. REv. 815; Kent, Some Further Ncecssary Amcndments to the Uniform Negotiable Instruments Law (192S) 22 IL. L. REv. 833.

1s See particularly Professor Kent's article, supra note 17, and Note (1928) 28 CoL. L. Rev. 648. 
this latter view the writer concurs, but owing to space limitation this article will be restricted to a consideration of only the more important of the suggestions of the draftsman as seen in the light of the foregoing discussion, and will only incidentally deal with further suggestions.

The first two amendments ${ }^{10}$ suggested relate to the scope of the act, and in particular to the decision of the New York Court of Appeals in declaring interim certificates to be non-negotiable as not conforming to the act. ${ }^{20}$ The decision was unfortunate, and it is believed unnecessary, for, as has been pointed out, ${ }^{21}$ it has never been thought that the act had any bearing on the negotiability of instruments such as bills of lading, warehouse receipts and stock certificates. By definitely restricting the act to instruments for the payment of "money," it is believed the result will conform to the general understanding and convenience of the community.

With this added stress on the term "money," however, and in view of the considerable uncertainty in the common law decisions as to what constitutes money, some attempt should be made to define the word.22 It is sometimes confused with legal tender. There has been further some disposition to require a showing, in the case of items drawn in foreign currencies, that the currency in question actually circulates to some indefinite extent in the particular community. ${ }^{23}$ The problem arises increasingly in foreign trade and banking through the use of foreign currency paper. While the more recent judicial view ${ }^{24}$ inclines to sanctioning all foreign currency, viewing the fact that the particular item was taken as proof of circulation in the community, the situation is highly uncertain. The following is suggested by way of amendment to section 191:

Money means any circulating media, whether legal tender or not, and whether circulating at par with legal tender or not, which have been issued as part of its currency ${ }^{20}$ by or with the sanction of any government or state, domestic or foreign.

19 It is proposed to amend the title to read "A General Act Relating to Negotiable Instruments for the Payment of Money," and to amend the first sentence of \& 1 to read "An instrument for the payment of money which conforms to the following requirements shall be negotiable." The point might well have been assumed.

20 Manhattan Company v. Morgan, 242 N. Y. 38, 150 N. E. 594 (1926). 21 (1926) 35 YALE L. J. 877.

22 The uncertainty concerning the term is ably discussed in Oliphant, The Theory of Money in the Law of Commercial Instruments (1910) 29 YALE L. J. 606, in which substantially the view hereinafter suggested is advocated.

23 Black v. Ward, 27 Mich. 191 (1873).

24 Brown v. Perera, 183 App. Div. 892, 176 N. Y. Supp. 215 (1st Dept. 1918), aff'g 182 App. Div. 922, 169 N. Y. Supp. 1086 (1st Dept. 1918).

25 The litigation as to what is taxable under the Federal statute impos- 
This should have the merit of requiring little or no further recourse to the courts on the point as practically all currency would become "money" for purposes of the act."s Further there would be no need of proving in any case that the particular currency was in circulation in the community as money. It is believed that such a view would be fully in accord with the understanding and convenience of the financial cormmunity, whose operations necessarily transcend government lines. It is further not perceived how there could be any overreaching involved; in fact, quite the contrary. But in this, as with other proposals under consideration, there should be careful investigation of all aspects of the question factually.

The fourth proposed amendment ${ }^{2 z}$ is to define "current funds" as any "circulating media" which were "lawfully and actually circulating at par with legal tender" when the item in question was issued.2s The courts have experienced considerable difficulty with the term "current funds." The difficulty is two-rold; whether an instrument so drawn is payable in money so as to be negotiable, and whether it calls for legal tender money or not. It is fairly clear that banks, who are the principal users of this and similar terms, intend definitely to negative the view

ing a tax on circulating notes other than National Bank Notes should prove of help in reaching a fair interpretation of this definition. See 12 U. S. C. $\$ 562$ (1927).

${ }^{26}$ A qualification which might reasonably be made would concern instruments both drawn in terms of foreign currencies and requiring payment in such media. This could be covered by amending $\$ 6$ (5), by inserting the word domestic so that the section would provide that the negotiable character of an instrument is not affected by the fact that it "Designates a particular kind of current domestic money in which payment is to be made."

${ }_{2 \pi}$ The third suggestion is to amend the first sentence of $\$ 3$ which reads, "An instrument is not negotiable which contains an order or promise to do any act in addition to the payment of money," by adding the proviso, "unless such additional act is apparently intended to render more secure and certain the payment of the sum of money to which the order or promise relates." The proviso has been criticized as altogether rague. See Britton, op. cit. supra note 17, at 817 . In this the writer concurs. Moreover, stated positively, it would seem that the amendment would mean that the insertion of any clause which could meet this description would by that fact render any instrument negotiable. The provision would have no effect in the case of trade acceptances, which some courts, relying more on the dictum that a negotiable instrument is a courier without luggage than on the statute, have declared to be non-negotiable. See Lane Co. v. Crum, 291 S. W. 1084 (Tex. 1927); (1928) 37 YaLe L. J. 382.

28 The amendment, which except for one change was originally suggested by Brannan, supra note 16, bristles with questions which would require court interpretation. For example what is means by "Jawfully and actually." To what extent must the "circulating" talie place? Will evidence of circulation be restricted to the day the item in question was issued? 
that payment can be restricted to legal tender. The proposal of the committee sanctions this, but with the proviso that the medium used in effecting payment must have been circulating at par with legal tender at the time the item was issued.

The writer is not advised what, if any, fact investigation serves as a basis for this qualification. With the broader definition of money suggested above adopted, much, if not all, of the present court difficulty would disappear. ${ }^{20}$ The committee's qualification, however, promises to cause considerable litigation should it become necessary in any large number of cases to prove that a certain currency which has since become depreciated was, on the day the principal item was issued, circulating at par. Furthermore, the proposal, it is believed, will not be widely understood and may therefore result in many parties being misled. It would seem that the following provision would better serve the purpose, unless it be shown that the phrase has resulted in overreaching by the banks in a way which can be avoided by the means suggested:

\section{"The term 'currency,' 'current money' or 'current funds' means any domestic money."}

The next question taken up for amendment relates to whether a special indorsement on bearer paper should control its future negotiation. ${ }^{30}$ The point is one raised by Dean Ames who early

29 This would be true, as the question whether an item drawn payable in "current funds" would be negotiable or not would be settled in the affirmative. It would not be necessary to identify current funds with legal tender in order to show that the instrument was payable in money. Sco Bull $\nabla$. Bank, 123 U. S. 105, 112, 8 Sup. Ct. 62, 64 (1887), in which the court says, ". . . the term 'current funds' has been used to designato any of these (gold, silver or legal tender notes), all being current and declared by positive enactment to be legal tender." In view of such decisions, however, it may be necessary to declare that "current funds" refors to monoy as above defined, but is not limited to legal tender money. To limit the item to legal tender would exclude the possibility that payment might bo made in Federal Reserve Bank Notes, for example, which are not legal tender. The root of the difficulty, though, is the failure to define monoy.

30 The present $\S 9$ (5) reads: "the instrument is payable to bearer . . . When the only or last indorsement is an indorsement in "blank." It is first proposed to add to this the sentence, "when an instrument payable to bearer is specially or restrictively indorsed it ceases to be payablo to bearer and becomes payable according to the terms of the indorsement." It is next proposed to strike out $\S 40$ which reads, "Where an instrument, payable to bearer, is indorsed specially, it may nevertheless be furthor negotiated by delivery; but the person indorsing specially is liable as indorser to only such holders as make title through his indorsement."

As technical criticism of the amendment to $\$ 9(5)$, assuming its advisability as a matter of policy, which is questioned, it may be said first that it leaves the status of specially indorsed paper hopelessly uncertain. Having ceased to be payable to bearer, and not being payable to order, it might 
pointed out a possible conflict between sections $9(5)$ and 40 of the Negotiable Instruments Law. ${ }^{31}$ It must be said, however, that in thirty years there has been no decision taling Dean Ames' view. It is entirely clear that neither the English Act, the common law decisions, nor, for that matter, the decisions or statutes in this country, allow a special indorsement to control the subsequent transfer of paper originally drawn payable to bearer. As to paper drawn to order and made payable to bearer by being indorsed in blank, it is believed to be equally clear that a special indorsement following the blank indorsement does control subsequent transfer. To make this certain, however, all that would be needed by way of amendment would be to insert the word "originally" before the phrase "payable to bearer" in section 40.

The proposed legislation would cure the supposed conflict between section $9(5)$ and section 40 by taking an entirely new position. The result would be somewhat more symmetrical, in that paper originally drawn to bearer would be put on the same footing with paper drawn to order and endorsed in blank; but it is not clear that this is more than a minor consideration. As to the desirability of the proposal, it must be recognized at the start that it will require some readjustment-especially on the part of drawee and collecting banks. It is fairly clear that, as is suggested by Professor Williston, to provide that a special indorsement should control the subsequent transfer both of paper indorsed in blank and paper originally drawn to bearer, worlis to the advantage of the holder since, if he is in possession of such paper he may protect his ownership by so indorsing it. But as to all other parties concerned, it increases the risk of dealing. For example, subsequent purchasers would run the risk of a forged indorsement, a risk no greater than on other types of indorsed paper, but one that has heretofore not existed on paper originally made payable to bearer. The same increased risk

well be regarded as non-negotiable. And further, if it were to be again indorsed in blank what would be its status?

31 The supposed conflict is seen by assuming that the reference to bearer instruments in the first part of $\$ 40$ must include blank indorsed order instruments which have subsequently been specially indorsed. This, in the face of the fact that $\$ 9$ (5), the section defining bearer instruments, expressly provides that an order instrument can only be treated as payable to bearer "when the only or last indorsement is an indorsement in blank," thus making it painfully clear, it would seem, that $\S 40$ has no application to such paper. This granted, there is no conflict. To insist on the vier that a conflict exists is to attempt to embarrass rather than assist the fair administration of the statute. The point would not be important except that Professor Williston again asserts that there is a conflict and one which must be corrected by amendment. In the face of this insistence it is a little difficult to give the other aspects of the proposed amendment a fair hearing. 
applies to the maker or acceptor. At present, a payment in due course to any bearer is protected as a good payment. ${ }^{32}$ of course, with the amendment, a payment to one holding through a forged indorsement might, in theory, be recovered. At the same time this matter of going back on a long chain of indorsements, which the amendment would make necessary, is practically a slow and unsatisfactory procedure. As to the acceptor or maker, in the cases where he had learned of the forged indorsement before payment, it would work to his advantage to be given the defense that the holder might not recover as bearer, but these cases are relatively rare. Further it is odd that, although a maker may have issued his paper in bearer form, he should be protected in this way by the fortuitous circumstance that some holder might by specially indorsing it have changed its character to order paper..$^{33}$ Probably, though, the great majority of cases would be made up of checks drawn to bearer and handled for collection. It is a much simpler procedure for collecting banks to be relieved of indorsement troubles as at present on bearer items. Moreover, since the ultimate loss in case of forged indorsement under the proposed amendment would, as a practical matter, often be placed on the collecting bank handling the item without charge, the amendment would seem to bring about an unnecessarily unfair result.

Taking a somewhat broader view of the matter, in many European countriès the purchase in good faith and for value of any negotiable instrument, even though drawn to order and specially indorsed, operates as a transfer notwithstanding there may have been an intervening forged indorsement. ${ }^{34}$ In England by section 60 of the Bills of Exchange Act, the effect of forged indorsements insofar as the payment and collection of checks is concerned, is largely brought within the continental rule. The houses in this country dealing with foreign countries are continually having difficulty because of the different effect we ascribe to forged indorsements. ${ }^{35}$ Of course, if the commit-

32 The argument is made by Brannan that the present rule as to paper originally drawn payable to bearer would allow payment to be mado to an individual bearer in disregard of a "Pay any Bank or Banker" indorso. ment. BRANNAN, op. cit. supra note 1 , at 328 . Of course this is misleading as payment must in any case, according to $\S 88$, be made in due course; and to pay.an unknown individual presenting bearer paper so indorsed could hardiy be said to be a payment in good faith without notice.

33 Although the maker were to pay his instrument, but to a person who had forged a special indorsement of some prior party, he could be requirod to pay again to the real owner. Practically, the payment to the forger might not be recoverable. It would be hard to explain to tho makor, thus required to make double payment, that the result was entirely justified.

34 Lonenzen, The Conflict of Laws Relating to Bills and Notes (1919) 47.

85 For discussion of whether the American or European law should 
tee is willing to advocate legislation similar to section 60 of the Bills of Exchange Act and possibly sections 80 and 92 relative to Crossed Checks, in regard to which something might well be done, there would be much less ground for criticism. Otherwise the proposed amendment would seem to be a step in the wrong direction.

But before any conclusion can be had, it should be clear that there are a great many points that will bear investigation. The case would seem to fall within the principles discussed above in connection with the certification of raised checks; the loss, if any, would in each case result from a third party's wrong doing. Can the question, who may best avoid the loss, be answered? Certainly it may be said that care on the part of holders of such paper may obviate many losses. The proposed action would increase the risks of bona fide purchasers, makers, acceptors and collecting banks in ways that would be difficult for them to avoid, in order to give greater protection to the holder, however careless he might have been. Unless there are facts not yet disclosed it would seem the better course to continue the present rule, leaving it to the holder either to refuse paper originally made payable to bearer or to insure against the rish of its loss. In this last respect, since the parties concerned include the whole financial community, it would seem impossible to say that the holder is any less able to insure against possible loss than the others.

Three amendments are proposed to correct the conflict relating to whether a payee may be a holder in due course. Of these the most important is that amending section 30 so as to provide definitely that negotiation of an order instrument may not only be in the usual way by indorsement completed by delivery, but also by delivery alone "to the person to whose order it is payable," or, more briefly stated, to the payee. It has been this point which has caused the most difficulty in the courts, the argument being that inasmuch as the definition of negotiation in the Act does not expressly cover delivery to the payee, it could not be said in such a case that there had been a negotiation to the holder as contemplated by section 52, the section defining holder in due course. But to make the matter doubly certain a further amendment has been proposed definitely mentioning the payee as one who may be a holder in due course.:

govern in the case of a transfer of a negotiable instrument abroad, see Comment (1928) 37 Yare L. J. 803.

36 The first sentence of $\$ 52$ if amended as proposed rould read: "A holder in due course is a payke or other holder who has talien the instrument under the following conditions: . . ." (the words in italics being added).

Subsection 4 of $\S 52$ at present reads: "That at the time it was negotiatcd 
There seems to be no dispute among writers but that it is desirable that the payee should be accorded the protection given other holders taking paper in good faith and for value.

The third amendment of this group relates to the requirement of delivery, which "as between immediate parties, and as regards a remote party other than a holder in due course," to use the language of the present section 16, "must be made either by or under the authority of" the maker or other party if it is to be effective. The proposal is to omit the phrase "as between immediate -parties" making the sentence in part read simply, "as against a party other than a holder in due course . . ."

The omission of the reference to "immediate parties" is desirable as things now stand, in view of the uncertainty as to who are immediate parties, but the section as amended is not satisfactory. An illustration should make this clear. Suppose an agent acting on behalf of the maker', but in excess of what a court would ultimately declare to have been his apparent authority, were to deliver the paper for value to the payee. By sections 30 and 52, if amended as above proposed, the payee would no doubt qualify as a holder in due course. He would have satisfied all requirements, if indeed he became a holder. But on this point, the definition is very broad and he could no doubt come within it, there being no forged indorsement involved. The result would thus be that a fundamental requirement in contract law, that providing for an authorized delivery between immediate parties, would be stricken out; a more serious defect than that sought to be corrected.

There is no need of doing this much violence to the present rules, but at the same time it must be made clear that in cer-

to him he had no notice of any infirmity in the instrument or defect in the title of the person negotiating it." It is proposed to amend this to read: "that at the time he became a holder he had no notice of any infirmity in the instrument or that the title of the person negotiating it was dofective or that the delivery to himself was wrongful."

The insertion in the opening sentence, although strictly unnecessary in view of the definition of holder, may be approved in the interest of certainty. The remaining amendments, however, are not only unnecessary but undesirable. Having amended $\S 30$ to define negotiation to include delivery to the payee, there was no need to substitute "became a holder" for tho present wording. The attempt is apparently to re-describe in $\S 52$ (4) what has already been done in $\S 30$. This in itself is undesirable. Further, the phrase "or that the delivery to himself was wrongful" would add a new test which every holder, whether payee or not, would have to satisfy hereafter to become a holder in due course. And what is meant by urongful? As the writer has pointed out elsewhere the clause would also confuse the interpretation of $\S 14$ inasmuch as it appears to have set up two types of holders in due course: those to whom the item has been negotiated and those to whom it may have been delivered. Book Review (1926) 36 YALE L. J. 158, 159. It would be better to leave the subsection in its present form. 
tain situations, at least, the payee and maker, to use but one illustration, are not to be regarded as immediate parties. T'he direct way would seem to be to leave the section as it is now worded, defining "immediate parties" to make the point clear, a matter which should be covered in any case if the term is to be used later in the act as has been suggested. The writer would favor making the right of recovery by the holder, whether he be payee or subsequent indorsee, depend, in the case of unauthorized delivery by an agent, on whether the party receiving the instrument knew or had reason to know of the agency.: In other words no adequate reason has been advanced for taking from the maker the defense of unauthorized delivery in cases where the taker knew he was dealing with a representative. On the other hand where the agent purports to be owner of the paper, and the taker is reasonable in assuming him to be owner, the defense of unauthorized delivery should be cut off. Professor MIoore's argument relative to so-called remittance paper is another way of illustrating the point.3s That is, when a payee or indorsee takes a bank draft or other instrument of the remittance type from a supposed owner who is, however, not a party, the payee should be given as much protection as would be accorded an indorsee. It is doubtful whether the rule should be limited to so-called remittance paper, as the form of the instrument would seem to be important primarily to show that the holder acted in good faith in assuming the one in possession of it to be an owner. Moreover, even though remittance paper is purchased, if it is taken from a known agent, who in fact exceeded his authority, there is no point in protecting the purchaser.

As to the possibility of accurately defining irnmediate parties so as to reflect this distinction, the following is tentatively suggested:

"Immediate parties" refers to any party whose signature appears on the instrument, and the next subsequent party to whom it is delivered, unless it is delivered by a third person, and the party receiving the instrument did not know or have reason to know that the third person held the instrument as agent or other representative of the first party. Where delivery is made by one of several joint signers, not partners, only the signer making delivery and the party receiving the instrument are immediate parties.

The exception in the first sentence is to provide for the usual payee as holder in due course situation, and equally for the simi-

37 For a careful analysis of the different situations in which the problem may arise, see Comment (1927) 36 YArE L. J. 1005.

ss Moore, The Right of the Remitter of a Bill or Note (1920) 20 CoL. L. Rev. 749 . 
lar problem when delivery is made by a third person to a specinl indorsee. The second sentence is designed to resolve all doubts, for example, in the co-malker situation. It seems to go rather far, in fact to the extent that would apparently obtain in all cases under the proposed amendment to section 16. But in the case of accommodation makers who, for example, may have given the paper to the principal debtor on condition that other signers be obtained, the delivery to the lender who takes it in good faith should be conclusive. Otherwise it would be necessary to insist that the paper be made to order of the debtor and indorsed, or to inquire of each signer before taking the paper whether there were defenses, both somewhat cumbersome. As to signers who are actual parties to the transaction with the payee, the situation itself should afford them sufficient protection in their opportunity to attack the good faith of the payee and thus his standing as holder in due course.

Another problem ${ }^{30}$ sought to be resolved by amendment relates to whether a maker who signs a note for the accommodation of the payee may be held liable should the instrument not be sold until after maturity. The Act at present does not expressly cover the point, although it provides in section 29 that "such a person is liable on the instrument to a holder for value, notwithstanding such holder at the time of taking the instrument knew him to be only an accommodation party." This could be construed as meaning merely that the element of notice should not defeat recovery assuming the holder in other respects should be a bona fide purchaser for value before maturity. On the other hand many courts have ruled that the term "holder for value" controls, and have allowed recovery even where the instrument was not negotiated by the accommodated party until after maturity. ${ }^{40}$

In this situation Professor Williston has suggested that the section be amended to provide that if the maker did not intend a transfer after maturity, the negotiation should be regarded as "a breach of faith." Obviously this fails of its purpose if you ask what are the consequences of such a breach of faith, a matter not provided for. It has always been supposed, although no cases are at hand, that if the holder, even a holder for value, had notice of defenses, he would not be entitled to recover of the

\footnotetext{
${ }^{30}$ It is also proposed to amend $\S 23$ to read: "when the signature of a person is forged or made without authority it is inoperative to render him liable or to transfer his rights under the instrument unless he is precluded from setting up the forgery or want of authority."

This amendment probably makes no change in the law and would seem to be unnecessary although the proposed wording is to be preferred to the former which declared that a forged or unauthorized signaturo is "wholly inoperative."

\$0 See discussion in (1926). 24 MICH. L. Rev. 847.
} 
accommodation maker. This is consistent with the view advocated by Brannan, that "holder for value" in the present section should read "holder in due course." sr The proposed amendment could quite reasonably be interpreted, however, as meaning merely that the maker might sue the payee for the breach of faith, saying nothing as to whether a holder for value purchasing the instrument after maturity without notice of such breach could recover or not. The situation in need of amendment would thus be unchanged.

The unknown quantity in the case is as to what the maker understands his contract to be. Does he intend that he shall be obligated in case of negotiation after maturity? If he does so intend, obviously the holder in due course requirement would be unsatisfactory as a purchaser after maturity could not qualify. It would seem to be necessary to make a thorough investigation of what business people think is, or should be the proper view, thus insuring as far as possible that the result will accord with general understanding and convenience. Perhaps such an inquiry would show that ordinarily negotiation after maturity is not intended. If so, this view no doubt should be codified, but if a maker were to intend that negotiation could be had after maturity as.well as before, it should be left clear that the purchaser in such case, although not a holder in due course, would be entitled to recover, a possibility probably precluded by the wording of Brannan's suggestion. If this view were to be sustained by the facts, it would seem better draftsmanship to omit all reference in section 29 concerning the obligation of the accommodation party to one or another holder, making it cover merely the effect of notice of accommodation signing. The following is suggested:

Although a holder may have known at the time of taling the instrument that such person was only an accommodation party such knowledge shall not constitute notice of any infirmity in the instrument or defect in the title of the person negotiating it.

The next two amendments, ${ }^{42}$ taken in order as drafted, refer to the status of bank notes and demand certificates of deposit under the Act. The first, an amendment to section 53, is designed to make sure that a purchase of such an instrument may be made at any time, thus avoiding the possibility that a purchaser might be said to have taken subject to defenses. As to bank notes, the amendment is harmless but of little value as it

\footnotetext{
11 Brannan, op. cit. supra note 16, at $494-500$.

42 It is also proposed to amend $\$ 37$ to provide in effect that a restrictive indorsee for account of a third party may qualify as holder in due course. The amendment corrects an error in the present act and should be approved. Section 47 is also amended to conform.
} 
is inconceivable that any court at any time under any circumstances would have ruled that one taking bank notes, or in other words money, should by reason of this hold the instrument subject to claims of prior holders. As to demand certificates of deposit, which of course may well be outstanding for a considerable period, it would seem the present reasonable time requirement is sufficiently elastic to allow of full justice being done. ${ }^{43}$ Certainly no reason in decision or fact is advanced for the position taken by the proposed amendment, that a bank should be entirely deprived of this defense, one common to others issuing demand instruments. Obviously if due allowance is made for what should constitute a reasonable time under the circumstances, as we may trust the courts to do, the amendment is not necessary ordinarily for the protection of holders.

The other of these two suggested amendments would make section 70 of the Negotiable Instruments Law read:

"Presentment for payment is not necessary, except in tha case. of bank notes and certificates of deposit, in order to charge the person primarily liable on the instrument."

This point also is one which in thirty years has caused no difficulty in the courts. It was first suggested by Dean Ames, and has been approved by all subsequent commentators, except Brewster who appears to have thought the point somewhat academic. The wording of the amendment as it now appears was proposed by Brannan.44

There is probably no disagreement with the evident purpose of this amendment, assuming that it is necessary. It is interesting though to see how it may most plausibly be construed if adopted as now drafted. It is fair to state in the language of the section, if amended as proposed, that hereafter presentment would be necessary to charge the bank on a bank note or certificate of deposit. That being so, what constitutes due presentment. This is evidently provided for by section 71 , the next section, and by it, for example, the holder of a 30 day certificate of deposit would be required to present for payment on the maturity date to charge the bank, an absurd result.

The difficulty lies in failing to distinguish between presentment to charge secondary parties, and the pleading rule requir-

43 The present $\S 53$ provides, as to all types of demand instruments, that if they are negotiated an unreasonable time after issue, the holder is not deemed a holder in due course. The amendment would sanction negotiation at an unreasonable time after issue. Thus, in case a bank were induced by fraud to issue a certificate of deposit, as in the case of a deposit of forged paper, there would no longer be any restriction as to the timo within which the certificate must be negotiated in order that the purchaser could become a holder in due course.

$\$$ BRANNAN, op. cit. supra note 1 , at 630 . 
ing demand in certain cases before suit may be had. It should be evident from the above, however, that even in the case of bank notes and certificates of deposit no presentment is necessary, just as the section provides, in order to charge the bank. At the same time, the Act does not affect in any way the quite different matter as to whether demand must be made as a prerequisite to suit, nor is there any provision as to what should constitute a due demand for such purpose. It is general information that demand by telephone for example would satisfy the pleading requirement though it would not satisfy the presentment rules..$^{25}$

While the two amendments proposed would seem to be immaterial, if not actually undesirable, the situation in other respects is not entirely free from doubts which might well be clarified. Of these the first relates to the proceedings necessary to charge indorsers on either time or demand certificates of deposit. By section 71 presentment for payment would seem to be necessary; in the case of time certificates, at maturity, and, as to demand items, within a reasonable time after their issue: To the writer, in view of the peculiar status of certificates of deposit as abore discussed, it is doubtful whether presentment of time certificates should be required strictly on the maturity day as apparently is the rule of the statute. Again there is considerable uncertainty in the decisions as to when the statute of limitations commences in the case of time certificates of deposit; whether at the maturity date or at the time of making demand. ${ }^{.3}$ Further in the case of demand certificates, if it be granted that the statute does not start running until the demand is made, should there not be some limitation, as for example twenty years, after which such a demand would be too late? Any of these three difficulties if resolved satisfactorily would be an actual contribution to the present statute.

The next amendment proposed by Professor. Williston would alter section 71 so as to reverse the present practice as to presentment of demand paper. The present rule as to the indorsers of a demand instrument other than a bill of exchange is that "presentment must be made within a reasonable time after its issue," or the indorser will be discharged from all responsibility. The rule concerning indorsers and drawers of demand bills is that presentment "will be sufficient if made within a reasonable time after the last negotiation thereof." In the case of checks, which for most purposes are regarded as demand bills of exchnnge, it

${ }_{15} \mathrm{As}$ to the inadequacy of presentment by telephone, see Robinson $\mathrm{v}$. Lancaster Foundry Co., 152 MId. 81, 136 Atl. 58 (1927); (1927) 37 YALE I. J. 258.

4G For general discussion of the problem see 2 PATON, DrGEsT (1926) 1056 a. 
is specially provided, however, that the drawer is discharged, but only to the extent of the loss, in case presentment of the instrument is not made "within a reasonable time after its issue." $4 \tau$

The difficulty has been the technical one of reconciling these provisions, and the practical one of justifying the distinctions made. The most apparent discrepancy is that a situation may exist where the drawer of a check, because of late presentment, will be discharged, at least to the extent of the loss, while the presentment may yet have been in time to charge the holder's indorser. ${ }^{48}$ In other words, presentment may be made an unreasonable time after issue, and yet within a reasonable time after the last negotiation. The proposed amendment abandons the "reasonable time after the last negotiation" test entirely, substituting as to drawers the "reasonable time after issue" test provided for in the case of drawers of checks. This is good policy, but as to indorsers, it is proposed to go back thirty years to the common law decisions, and provide that presentment of an instrument to charge indorsers must be made "within a reasonable time after its indorsement."

If we are to consult the convenience and understanding of the business community, it is believed that very little justification can be found for reversing the present rule as to indorsers of demand paper (other than bills of exchange), that is, for abandoning the reasonable time after issue test, in favor of the reasonable time after indorsement test. In fact it is doubtful if there is any reason, satisfactory to the users of negotiable instruments, why any difference should be made between drawers and indorsers in the premises. The writer is very much inclined to the view that only one test should be applied and that is the reasonable time after issue formula. To affect this all that would be necessary would be to amend the act as has been done in some states so that this section would read in part, "where it is payable on demand, presentment must be made within a reasonable time after its issue." ${ }^{49}$ This has the merit of ready application.

\footnotetext{
47 Negotiable INSTRUMents LAW § 186.

48 Columbian Banking Co. v. Bowen, 134 Wis. 218, 114 N. W. 451 (1908).

49 This is the Nebraska provision. Apparently similar legislation obtains in Vermont. BRANNAN, op. cit. supra note 1, at 638.

The criticism is made that this would not cover the case of time instruments indorsed after maturity, in that it would be impossible to present within a reasonable time after the issuance of the instrument to charge indorsers; also, that a demand note might well be indorsed an unreasonable time after its issue, again as to the indorser apparently making it impossible to comply with the reasonable time after issue test for presentment. Brannan, op. cit. supra note 1 , at 645 . As to the first, the common law theory was that the after maturity indorsement was similar to a new drawing and obviously presentment could be made within a reason-
} 
It is the present rule and may be assumed to be reasonably well understood. The proposed course would necessitate re-litigating the whole question as to what is meant today by a reasonable time after an endorsement.

Of perhaps more importance, would be a study of modern decisions and practices in order to state, if possible, a definite time within which presentment should be made in the cases investigated, or at least in many of the more important ones. That this can be done is proved by the fact that courts are continually called upon to undertake the task, and in fact have practically crystallized the rule with regard to the presentment of checks, where all parties are in the same city.5 It would seem quite possible that with the greater time and opportunity to investigate all phases of the question, the committee could satisfactorily state several such rules in definite terms to square with present requirements..$^{52}$ The additional gain to follow from the increased definiteness would easily offset the theoretical justice found in the flexibility of the present reasonable time rule.

The next amendments proposed by Professor Williston concern the discharge of an instrument, now dealt with in section 119, and the discharge of secondary parties, at present covered by section 120. The position taken in each case is again substantially that advocated by ${ }^{\circ}$ Dean Ames in his original criticism of the act, a position, it must be said, which appears to have been seconded by most of the writers on the subject. The basis of Dean Ames' argument seems to have been, however, merely that the law as expounded by common-law judges was different from the interpretation of the sections which he thought necessary. And from all that appears none of the subsequent writers has made an independent investigation from the facts as to the desirability of either position. While Dean Ames' attitude in the matter was perhaps right enough some thirty years ago when the chief end was merely codification, especially as his criticism was made to bring about revision before the Act had been widely adopted, it is obviously highly

able time thereafter. This result should reasonably obtain inasmuch as $\$ 7$ probably codifies the common law theory. The second point might rell be covered directly by amending $\$ 7$ so that it would read substantially as follows: "Where an instrument is issued, accepted or indorzed when overdue, or indorsed more than a reasonable time aftcr its issue if paybble otherwise than at a fixed or determinable future time, it is, as regards the person so issuing, accepting or indorsing it, decmed equivalent to a new insticument payable on demand."

50 For example, see Grange v. Reigh, 93 Wis. 552, 67 N. W. 1130 (1893).

51 The state of South Dakota has adopted definite time legislation distinguishing between interest and non-interest bearing demand notes and bills. See Brannan, op. cit. supra note 1, at 926. 
undesirable to attempt today to write out the thirty years of intervening experience without the most careful consideration.

The point is illustrated by the proposed treatment of section 120.52 It has been recommended that subsection 3, which now provides, in effect, that secondary parties, for example indorsers, are discharged "by the discharge of a prior party," should be entirely omitted. Dean Ames thought the provision was too broad since he considered that it might include a discharge by the statute of limitations or possibly by a bankruptcy discharge. This position has not been sanctioned by any court and, it is believed, is no longer maintained; it being understood the provision relates to discharges granted by the holder. It was further urged, although again no court has taken the position, that should a holder fail to charge a prior party, for instance by neglecting to give him due notice of dishonor, this too would be a discharge within the subsection, and would constitute a discharge of intervening parties. There would seem to be no danger at all that this view would ever be adopted by any responsible court.53

It is interesting to consider the legalistic situation which would follow if the subsection were to be omitted as proposed. Faced with a case involving an actual discharge, for example, of the

52 The present $\S 120$ reads:

"A person secondarily liable on the instrument is discharged:

1. By any act which discharges the instrument;

2. By the intentional cancellation of his signature by the holder;

3. By the discharge of a prior party;

4. By a valid tender of payment made by a prior party;

5. By a release of the principal debtor, unless the holders right of recourse against the party secondarily liable is expressly reserved;

6. By any agreement binding upon the holder to extend the time of payment, or to postpone the holder's right to enforce the instrument, unless made with the assent of the party secondarily liable, or unless the right of recourse against such party is expressly reserved."

${ }^{53} \mathrm{~A}$ further point is made against the subsection because of its possible application to a situation involving an accommodation makor. Seo BranNaN, op. cit. supra note 1, at 752. Here, should the holder dischargo the accommodation maker, the subsection would seem to operate to discharge an indorser even though he was the principle debtor, a result described by Dean Ames to be "shocking and contrary to all the decisions." Conceding the point for purposes of argument, the remedy is not to omit the subsection, but to add a proviso similar to that found in subsections 5 and 6 , that is, that secondary parties are discharged by the dischargo of a prior party, unless the right of recourse against such secondary parties is expressly reserved. It is the writer's experience that there are many occasions in practice when it would be decidedly convenient to be able to discharge one or another of the parties to a negotiable instrument without thereby discharging the others. It is not believed it would work to the disadvantage of any party. If this provision were added there would be little force left in the objection and, it is believed, the act would bo definitely improved. 
first indorser by release, what should a court rule as to the status of intervening indorsers? Presumably, if the repeal of the subsection were to be given any weight whatever, such parties would no longer be discharged-a result wholly out of harmony with the present business understanding. It is not possible simply to repeal the subsection and thereby be sure that forty-eight states will go back to the common law decisions, even if it were at all desirable, a point not in any way sustained.

But to proceed, it is proposed also to omit subsections 5 and 6 of section 120, providing respectively for discharge of secondary parties in case of a release of the principal debtor or of an extension of time being given, without recourse in either case being reserved against such parties.": The hope, apparently, is that by this means the courts will start again where they left off before the act was adopted. But even assuming this, no excuse whatever is advanced for omitting these provisions, at least, as they apply in the great majority of cases-those not involving accommodation parties. Surely it cannot seriously be recommended today that this codification, which to this extent has proven quite successful, should be abandoned for conflicting, uncertain and not necessarily satisfactory rules of suretyship, which it is assumed would apply inasmuch as an indorser's contract is a specialized form of suretyship. The argument, that inasmuch as the Act only inadequately codifies the suretyship rules it should include none of them, is not impressive. Moreover, no rule which the writer regards as of much practical importance in this situation has been specified as having been omitted, except the rule having to do with the effect of a release of collateral by the holder.:5 It would seem to be far better to provide for this case, and also to adopt such other rules as are shown to be essential, than to take the proposed action, unless of

51 The provision allowing a holder to preserve his recourze against secondary parties in these two cases has, it is believed, proven satisfactory. The argument for it is that it is decidedly convenient in many cases and probably in most will make no comparable difference to the parties against whom recourse is reserved. The suretyship rules which would obtain if these two subsections were to be stricken out would not admit of this possibility. While the scheme may no doubt be criticised as requiring an apparently meaningless formality on the part of the holder and as being uncertain as to what constitutes an express reservation of rccourse, it meets the test of convenience and is, it is believed, reasonably well understood.

5s The related problem as to whether a bank holding a depositor's instrument at maturity must apply his account in order to hold indoriers might also be covered. As to the many questions in suretyship concerning the effect on the surety's contract of changes in the agreement with the principal debtor, it is believed many of the refinements involred in this question have no place in negotiable instrument law and where important are covered by $\S 124$ concerning the effect of material alterations. 
course the committee wishes to abandon the idea of a uniform body of negotiable instruments law.

The more substantial criticism of the discharge sections relates to section 119, and applies only when one of the parties has signed for accommodation, or in other words as a "surety." It appears to have been the scheme of the Act to make no distinction between the contract of an accommodation indorser and that of an indorser selling the instrument for value. The same proceedings upon dishonor must be taken in the one case as in the other. And in the matter of discharge likewise no distinction was made. It is believed that where the accommodation party has signed as drawer or indorser, this has fully met with the convenience and understanding of those using commercial paper.

But when the accommodation signer, instead of appearing in a secondary capacity, signs as maker or acceptor for the accommodation of the payee, or as a co-maker, there has been difficulty. As a primary party it would seem such a signer would not, by virtue of section $119,{ }^{50}$ be entitled to discharge: for example, in event of an extension of time being granted to an indorser who might be the principal debtor. The great majority of courts, moreover, have construed the section to state the exclusive grounds for discharge in the case of primary parties and have thus refused to allow the suretyship defenses. or The result has been almost unanimously disapproved. ${ }^{58}$

It seems to the writer that the criticism of the result reached by the majority courts looks no farther than to see that the result is inconsistent with suretyship cases. If one consults the users of such paper, however, it is believed it will appenr that they definitely understand that a greater obligation is incurred by an accommodation party signing as maker than as indorser, a difference not explainable merely by virtue of the fact that in one capacity the signer is entitled to notice of dishonor, while in the other he is not. Moreover, from the standpoint of convenience, it would seem much better engineering to afford two possible courses in the accommodation situation; that is, to continue the result reached in most states today, thus mals-

56 The present $\S 119$ reads: "A negotiable instrument is discharged:

1. By payment in due course by or on behalf of the principal debtor;

2. By payment in due course by the party accommodated, whero tho instrument is made or accepted for accommodation;

3. By the intentional cancellation thereof by the holder;

4. By any other act which will discharge a simple contract for tho payment of money;

5. When the principal debtor becomes the holder of the instrumont at or after maturity in his own right."

57 The cases are cited in BrANNAN, op. cit. supra note 1, at 721, principal space being devoted to the few cases tending to take the other viow.

58 Ibid. 723. 
ing it possible to extinguish the suretyship rules where the accommodation party signs as maker, while leaving open the possibility that the signer, if that is his bargain, may go on the paper as indorser, with the increased protection accorded him in that capacity. This is especially true inasmuch as even where the signing is in a secondary capacity a great percentage of accommodation signers today, measured in amount of obligations, will be comprised of officers or stockholders of corporations, who sign for their company, or companies signing for a subsidiary, in neither of which situations are the refinements of common law suretyship particularly appropriate. Quite obviously there is much room in any event for a thorough fact investigation before any change whatever is approved. The one suggested would be worse than the rules now existing.

It is also proposed in this connection to omit subsection 4 of section 119.59 The reason for this action originated with Dean Ames, since in his opinion the wording "by any other act which will discharge a simple contract for the payment of money" was entirely too broad. In his view a payment before maturity could even be said to come within the section so that if the instrument by some means were thereafter to be negotiated to a holder in due course, the latter might not recover. This view has not been taken by the courts. ${ }^{c 0}$ It has been considered that the subsection applies merely as between the parties.

The confusion appears to be brought about because of the uncertainty as to whether or not a discharge of this character should rank as a real defense. As the section probably is otherwise limited to real defenses, the question might be clarified by inserting a provision limiting the application of the subsection to acts occurring after maturity. Thus the subsection might well read, "By any other act at or after maturity which would discharge a simple contract for the payment of money." Certainly a release by the holder of the party primarily liable given at or after maturity should rank as a complete discharge, ${ }^{62}$ and,

${ }^{59}$ Supra note 53.

co BranNan, op. cit. supra note 1 , at 742 .

61 To make sure that, as between the parties, a release or other discharge would still be effective, it is proposed to add the following sentence to $\S 120$ :

"As between immediate parties any defense is effectual which would be a defense to a simple contract for the payment of money."

It is doubted that any provision is necessary to accomplish the supposed parpose of the committee. The proposed action, however, is indeinite "in its use of "immediate parties" without definition. And what of a release by a remote party?

A still more serious objection, perhaps, would arise in case an indorsee claiming to be a holder in due course were to sue his indoreer. At present the act would admit of the indorser showing that the indorsee did not qualify as holder in due course and, when shown, allow any defense good in the 
if there is any doubt whether this comes within the subsection relating to payment as discharge, it would be unwise to omit subsection 4 limited as suggested. ${ }^{62}$

Another flaw, or supposed flaw, in the act to be remedied is the possibility that in event of an accidental alteration or spoliation the instrument would be discharged-a position maintained as a reasonable, in fact necessary, interpretation of the present section by all writers from Dean Ames on, but not sustained to any important extent by the courts. In fact the Judicial Committee of the Privy Council, within the year, has had before it a striking case which illustrates this. There, a $\$ 500$ note was accidently altered when the clothing in which it had been left was washed. The opinion discussed at considerable length whether a material alteration occurring in this way should avoid the instrument, under section 64 of the Bills of Exchange Act, which was substantially copied in section 124 of the American Act. In holding that the section did not include such alterations the court stated that:

"Both the history of the law which this section enunciates and the terms of the section itself show that it relates only to alterations effected by the will of the person by whom or under whose directions they are made, and that it does not apply to a change due to pure accident." ${ }^{63}$

case of a non-negotiable instrument, whatever that may be. The now sentence would reach this position at once-a much broader proposition; probably negativing much of the law peculiar to negotiable instruments.

62 The serious question in these payment cases, and one not touched upon by the committee, relates to accelerated instruments paid before their fixed maturity date. Should a subsequent purchaser unaware of such facts be protected? The same situation is presented in the case of instrumonts payable "on or before" a fixed date. And, in the case of demand instruments paid and subsequently wrongfully put into circulation, the situation is not clear, although in the analogous case of omission to give due notice of dishonor followed by sale to a bona fide purchaser the latter is protected. It is suggested as a partial answer to these problems that substantially the following be added to $\S 88$, the section defining payment in due course:

Payment of an instrument drawn payable on or before, or whose maturity date may be accelerated before, a fixed or determinable future time, if made prior to such time, or of an instrument payable otherwise than at a fixed or determinable future time, before a reasonable time after its issue has elapsed, shall be in due course only if the payment is indorsed on the instrument or the instrument is delivered up to the party making payment.

There are obviously many questions as to the desirability of legislating in this fashion. These should be carefully considered. But the point is real and of much more importance than the practically non-existing difficulty with $\& 119$ (4).

63 Hong Kong \& Shanghai Banking Corporation v. Lo Lee Shi, [1928] A. C. 181. See the able discussion of the case in (1928) 44 L. Q. REv. 401 , in which it is suggested that, while the result is satisfactory, it may. 
It is proposed to cover the point expressly, however, by amending section 124 to read in part, "Where a negotiable instrument is fraudulently and materially altered by the rightful owner ... it is avoided ..." The italicized words would be added to the present section. It has been pointed out that nobody lnows who is a "rightful owner," $c$ and the term, holder, is probably to be preferred. But a more serious criticism is apparent when you ask what will happen hereafter if a remote holder; for example, were to agree with the maker to change the interest rate. The alteration would be material but it could hardly be said to be fraudulent. What would be the result as to indorsers not assenting to the change? A court might well assume that the amended section was intended to change the prior law and thus reach the result that such an alteration would no longer constitute a discharge. If this were to follow, and it would seem to be almost a necessary conclusion from the language used, it would be better here, too, to leave the section in its present form.

The discussion discloses, however, a further purpose which the present section 124 serves, which would be equally defeated if it were amended as proposed. One of the points on which the act was attacked by Dean Ames was that the suretyship rule, providing for discharge of surety in case of subsequent change in the principal agreement, was not adequately codified by section 120 discussed above. But changes would ordinarily have to be made on the instrument if the malier were to be protected and in such case the present section would be effective usually to declare secondary parties discharged in accordance with the suretyship rule. The section does this without at the same time burdening negotiable instruments law with the many fine distinctions as to what would be a material change in the principal agreement.

The responsibility to be imposed on a drawee, who destroys or refuses to return on demand a bill of exchange left with him for the twenty-four hour period provided in the act for acceptance, has given rise to another difference of opinion. At the time the act was drafted, several states, including New York, had statutes providing that such action should count as an acceptance. The rule at common law was that it amounted to a conversion, thus making it necessary for the holder in each case to prove the value of the instrument before he might recover. The draftsmen of the act adopted the statutory rule which they found had proven to be a practical working rule. But to call a refusal to accept an acceptance was to Dean Ames a "perver-

not be sound historically as a question of law, although the situation might well be one in which an equity court would have intervened.

es Britton, op. cit. supra note 17, at 828. 
sion of language," ${ }^{55}$ and the proposed amendment compromises by calling it a conversion, but one for which the damages are fixed at the face value of the instrument.

In most cases it would seem utterly immaterial whether the term "acceptance" or "conversion" be used, if the recovery is to be the same in either event. If called an acceptance, however, it is clear that no recourse could be had against the secondary parties until the item should be presented and dishonored for non-payment. But as this is exactly what the holder and secondary parties bargained for, it would seem entirely just. As to the position of the drawee, if he were required to pay as "acceptor," he might readily recover of the drawer, but as a "converter" his position might well be doubtful. This is an unnecessary result_if merely to cure a "perversion of language"-and should not be brought about except on a showing of practical necessity. Moreover, the present section has been quite reasonably interpreted to require an intentional destruction in order to constitute an acceptance. ${ }^{\text {s6 }}$ The amended section might well be so construed but to say unqualifiedly that it constitutes a conversion is to court the possibility of misinterpretation.

In the courts the difficulty with the section has been two-fold: first, in failing to note that there must be a refusal to return the instrument in order that the retention of it should amount to an acceptance; next, that the section has no application to items left for payment. These points are easily cleared up; in fact they have already been corrected in one or two of the states where they have caused difficulty. ${ }^{67}$ But the draftsman proposes to go much farther and to make the section apply to any item left with a drawee, whether for acceptance, certification, or payment. ${ }^{68}$ As it now stands the amended section would produce the somewhat remarkable result, at least by implication, that the drawee of a check might have twenty-four hours in which to certify or pay ${ }^{60}$ But even if this were corrected, it seems

65 BRANNAN, op. cit. supra note 1 , at 838 .

${ }^{66}$ Bailey \& Co. v. S. W. Veneer Co., 132 Ark. 63, 200 S. W. 280 (1918).

or BRANNAN, op. cit. supra note 1, at 839.

68 The section as amended would read:

"Where a drawee to whom a bill is delivered for acceptance, certification, or payment destroys the same, or refuses on demand made after the expiration of twenty-four hours after such delivery or such longcr period as tho holder has allowed, to return the bill accepted or non-accepted to the holder, the drawee will be deemed to have dishonored and converted the bill and shall be liable in damages for the amount thereof."

69 There would seem to be no point in putting a twenty-four hour provision in $\S 137$ inasmuch as it is definitely provided in $\S 136$ that the draweo has that much time in which to accept. It obviously has no application to items left for certification or payment. And even as to bills loft for acceptance, if they are destroyed or redelivery is refused within twontyfour hours, why should not the drawee be obligated? He might havo 
very doubtful whether every drawee destroying or failing to return on demand a worthless item presented for payment should be required to pay its face value to the holder.

It is suggested that the section be amended to read as follows:

Where a drawee to whom a bill is delivered for acceptance, destroys the same or refuses to return the bill accepted or nonaccepted to the holder pursuant to demand, he will be deemed to have accepted the same. This section does not apply to checks nor to any instrument presented for payment or certification.

It is believed that this would cure all the conflict encountered at present in the courts. Moreover, it would preserve the common law rule that the destruction of an instrument presented for payment would be a conversion, but not one for which the penalty is fixed at the face value of the instrument, as now proposed. In fact it is doubtful whether there is any occasion for legislating as to items left for payment or certification as there is no custom to leave items in this way, similar to the twentyfour hour practice in the case of bills left for acceptance. Only in the case of the present practice of collecting banks in routing items by mail directly to the drawee for payment would the situation arise. As to this, the Commissioners on Uniform State Laws voted at their last meeting to commence work on the drafting of a uniform bank collection statute. The American Bankers' Association, it appears, are also working on proposed legislation of this character. If found desirable to add this additional protection to the practice of handling collection items in this way, some provision limited to the needs of the case might well be inserted in that legislation. If so, it should obviously not only apply to items sent to drawees, but to all types of collection items, whether negotiable or non-negotiable, and whether sent to drawees or other parties.

Only one other proposed amendment is left for consideration. The present section 186 provides that,

"A check must be presented for" payment within a reasonable time after its issue, or the drawer will be discharged from liability thereon to the extent of the loss caused by the delay."

It was the Ames-Brannan contention that inasmuch as the section did not also provide for notice of dishonor, the drawer would be entirely discharged in case of failure to give notice. ${ }^{\text {to }}$

returned the bill unaccepted and inasmuch as he had not been given twentyfour hours as provided it should not count as a dishonor.

70 Since checks are to be regarded as bills of exchange as provided in $\$$ 185 , it would seem that the act requires protest also in the case of a ched: drawn in one state on a bank in another. If so, the point should be covered. 
Consequently it has been proposed to amend the section by adding after the word "issue," the following: "and notice of dishonor must be given to the drawer, as provided for in the case of bills of exchange, or the ..."

The purport of this amendment would be to legislate that, save for the situation where the drawee bank fails, causing loss, there is no requirement either to present or to give notice at any time. ${ }^{71}$ To continue the drawer's responsibility in the case of delayed presentment is to recognize that ordinarily he is the principal debtor. ${ }^{72}$ To use Dean Ames' favorite type of illustration, however, what would happen under the proposed wording in case the drawer happened to be an accommodation party? Should he not be entitled to notice in case the item was in fact duly presented but dishonored? The present section would provide an absolute discharge in this case. But despite this possible hardship it is believed the section, as amended, has much to commend it.

It remains only to make a few comments applicable to this case and, indeed, applicable to the entire project. It should be apparent that there are many points of view from which the present suggested amendments may be considered. While the present discussion has dwelt to some extent on supposed technical points of faulty wording, or again on whether many of the amendments are very material today, this has been only incidental. The principal question should be as to the reasons of policy which should be given chief weight; first, in drafting amendments already under consideration and next, in selecting other points in need of amendment.

The writer knows of no better way of ascertaining what constitutes good policy than to make as thorough an investigation from the fact side as time and money available will permit. It is, of course, of little help merely to consult the supposed function of a check, for example, or for that matter of negotiable paper in general, in order to reach a position. Such an effort assumes the point in issue. It would seem necessary, rather, to break up the question into separate factors, which it is assumed should

\footnotetext{
71 Probably still it would be necessary to present in order to commenco suit.

72 That this is the matter of chief importance is apparent if one considors the effect of the proposed amendment in a case involving duo presentment but faulty notice. The drawer would be discharged to tho oxtent of the loss caused by the delay, which in the case supposed could only be the delay in giving notice; if an entire failure to give any notice can be spoken of as a delay. What this would be is hard to say. Thero hus been considerable difficulty in determining what losses are caused by a failure to present in due time. See Ferrari v. First Nat'l Bank, 246 N. Y. 383,159 N. E. 178 (1927). The lower court decision, which was rovorsed on appeal, was criticized in (1926) 36 YALE L. J. 273.
} 
be considered in arriving at a decision. On the further assumption that the effort, in the last analysis, is to write in detail the contracts of the parties to negotiable paper, the principal considerations in the case of any suggested amendment would seem to be the understanding and convenience of the parties themselves, the possibilities of unfair practice and the extent of litigation to be expected. And further, in the case of losses through fault of a third party, it would seem desirable to take into consideration the relative ability of the parties to avoid the loss in the first instance, or to shift it to advantage.

That everything possible has been done to obtain data on these points is plainly not the case. To consider only the matter of discharges of party or instrument in the suretyship cases, it is very apparent that nothing worthy the name of fact investigation has been undertaken. When the act was originally prepared, the draftsman introduced an innovation in section 120 (6) whereby the holder might extend the time of payment and yet preserve his recourse against secondary parties. It is proposed to sweep this aside, without any investigation as to its workability, in an effort to conform to common law decisions. In other cases, as for example the reasonable time after issue test for presentment obtaining in Nebraska as to demand paper, it does not appear that any examination has been made of the practical working of the rule, thus ignoring the possibility that an improvement on the common law rule has been achieved. And, in the case of many newer questions, such as that involving the practicability of the Wisconsin legislation validating acceleration provisions, no investigation appears to have been made, nor in fact is any amendment suggested.

As one may perhaps have gathered from the foregoing it is the writer's opinion that common law decisions are of diminishing importance in the case of the negotiable instruments law. That statute has been in effect for over a quarter of a century. The present generation in commercial life has adjusted itself for the most part to the statute as drawn. It would seem almost imperative that the inquiry now must be whether the statute is meeting present conditions-not whether it squares with common law decisions. This is true not only in determining what view is to be adopted in the case of the present suggested amendments, but of perhaps more importance in determining what points are in need of legislative action.

This is simply to recognize that the work of the Commissioners on Uniform State Laws has in the case of the Negotiable Instruments Law, at least, reached a new and distinct stage. The committee is no longer chiefly engaged in codifying decisions. That was in great part done thirty years ago, and in the opinion 
of the writer, the statute, with all its defects, real and imaginary, has proven itself decidedly worth while. But if this work is to avoid crystallization, a distinct possibility, and is to attain full utility, some group must assume continuous responsibility for keeping it apace with changing times and conditions. It is believed there is no other group better qualified to assume such a responsibility than the organization which originally drafted the statute. 